\title{
Reflections on a policy denouement: the politics of mainstreaming zero-carbon housing
}

Gordon Walker, Lancaster Environment Centre and DEMAND Centre, Lancaster University, Lancaster, LA1 4YD

g.p.walker@lancaster.ac.uk

Andrew Karvonen, Manchester Architectural Research Centre, University of Manchester, Manchester, M13 9PL

Simon Guy, Faculty of Arts and Social Sciences, Lancaster University, Lancaster, LA1 4YD

\section{Abstract}

We reflect on the decision to abandon the mainstreaming of zero-carbon house building in England in the context of our paper that took this long-standing policy commitment as its case study. We consider this denouement as further evidence of how the exigencies of capital accumulation resist moves towards low carbon transition and reflect on what it reveals about the relation between politics and governance, the grounding and locating of carbon responsibilities and the necessary role of the state in enabling the everyday reproduction of low carbon living.

Keywords: carbon; housing; politics; governance

One of the hazards of researching ongoing policy processes is that events can catch up with you. As researchers, we are only ever making interventions in an ongoing flow of discourse and action, but sometimes a particular coincidence merits comment. Such is the case for our paper on zero-carbon and zero-carbon living (Walker et al 2015), which after much helpful reviewing, editor advice and revision appeared on-line just three days after the UK government scrapped the policy which the paper took as its case study. To recap this was (with an emphasis on the past tense) a policy applying in England to require all new homes to be zero-carbon (zero-C). This had been supported and developed (although also diminished) from 2006 onwards when the obligation was first announced and was due to come into force in April 2016. So after nine years of some degree of continuity and commitment through two political administrations, the 'rug was pulled' by the third ${ }^{1}$, just as this particular example of carbon policy was set to bite. There have been howls of protest from many quarters, not just those holding strong carbon commitments, but also from some parts of the housing and development industry who had been enrolled into the process of gearing up building designs, technology integration, supply chains and much else.

So how to interpret this policy denouement, given our concern with better understanding the embroiling of carbon in the sociomaterial interdependencies between built form and everyday living? One interpretation is to see the abandonment of zero- $C$ as further evidence of the resistances and inertias our paper identified as holding back change and actively reproducing the

\footnotetext{
${ }^{11}$ The newly elected Conservative Government as of May 2015, preceded by a Coalition Government (20102015) and Labour Government (2005-2010)
} 
sense of 'normal' held by those concerned with market value, house-selling and capital performance. Accordingly the announcement scrapping the zero-C obligation was located in a government strategy document 'Fixing the Foundations: Creating a More Prosperous Nation' released as part of the UK Treasury's 2015 summer budget, with an overarching narrative of government needing to release the power of capital to do its work for the UK economy (HM Treasury 2015). The recurrent UK trope of 'red-tape' is invoked in this document to wrap up zero-C with much else seen as getting in the way of the new house building needed to address housing shortages and generate new economic activity. A classically neoliberal justification then which, for us, vividly confirms how the exigencies of capital accumulation create resistance to transition and infrastructural lock-in.

At the same time, the abrupt abandonment of zero- $C$ calls into question our rather easy use of the notion of governance. Governance seemed an appropriate concept for framing both the general topic and the case study, given the collaborative nature of the process established in 2006 to work between government, industry and other actors towards implementing a target ten years distant. But we have now seen politics, rather than governance, at work. Latham has argued that:

'One way to understand the relationship between governance and politics is to conceive of governance as essentially postpolitical. Governance is always proximate to politics, but it is something that takes place after goals are set and deliberations, argument, struggle, contest, and competition have played out' (Latham 1999; 43)

It is now even clearer that politics - argument, struggle, contest, competition - never somehow stepped aside through the zero- $C$ process. Politics was always more than proximate, both internally manifest and externally ready to act to remove the apparently postpolitical sheen that had settled around the 'Zero Carbon Hub' - the not-for-profit organisation set up to take 'day-to-day operational responsibility for achieving the government's target' (Zero Carbon Hub 2015). There are undoubtedly lessons here both for actors drawn into apparently consensual processes built around notions of collaboration and mutual trust, as well as for the wider de-politicising consequences and outcomes of the use of governance language (Swyngedouw 2009).

A second interpretation focuses on the dynamic status and agency of carbon. In our paper, we showed how the concept of zero-C necessarily took home building into the realm of carbon calculation in which spatial, temporal and social ordering has to take place in order to put boundaries around home-carbon and make it governable. The nine years during which the zero- $\mathrm{C}$ policy was in place witnessed much 'boundary work' around this calculation, removing certain categories of home energy uses from its reach, and, particularly important for our analysis, eliminating any sense of dependency on how future homes would be lived in. These concerns notwithstanding, carbon was at least allowed some agency, as its regulatory status enabled carbon knowledge to inform how particular home designs were put together, how certain building materials and technologies were valued and how new methods of construction needed to be formulated, learnt and diffused. Taking away the necessity of calculation undoubtedly diminishes the agency of carbon and its potential effects on mainstream home building, as practice and product. A notional carbon responsibility does remain, given that there are national level carbon reduction targets and commitments still in place, but this has been re-scaled away from its grounding in built-form and the regulated local balancing of carbon production and mitigation, and back to a more diffuse and un- 
located form. Indeed, through the scrapping of zero-C, and a number of other recent policy shifts, it is becoming increasingly hard to locate any substantial grounding of carbon control ambitions by the current UK government, rather only their denuding and dissipation across space and time.

As a final reflection, we return to our recognition at the end of the paper of how sociomaterial interdependencies between built form and everyday living potentially can be harnessed in positive ways (in carbon and sustainability terms) by more socially and locally embedded models and forms of change. We emphasised how our analysis of zero-C home building was a case study of mainstreaming. We did not explicitly use the language of transition or deploy the analytical categories of the multi-level perspective (Geels 2010, Smith et al. 2010), but, if we had, this case might now be seen as an example of successful resistance by a dominant (housing) regime to the disruption posed by socio-environmental innovations (in eco-housing) emerging from protected niches. These categories remain rather clumsy, but they do capture something of the challenges involved in responding rapidly and at scale to the climate change agenda. Despite the excitement and enthusiasm that can accompany particular local examples of low (or zero) carbon living, moving at speed and at scale needs a state prepared to steer change (however imperfectly) towards transition. The state's ability to shape and locate investment choices and regulate and set performance standards is particularly important for those infrastructures that circumscribe, through their obdurate materiality, opportunities for the shared, everyday reproduction of low carbon living. Without this active government, any sense of transformation of low carbon living becoming a general right (Walker 2014), rather than only a diffused and problematically individualised responsibility, remains only a distant possibility.

\section{References}

Geels FW 2010 Ontologies, socio-technical transitions (to sustainability), and the multi-level perspective Research policy 39 (4) 495-510.

HM Treasury 2015 Fixing the Foundations: Creating a More Prosperous Nation Cm 9098, Stationery Office, London.

Latham R 1999 Politics in a Floating World: Toward a Critique of Global Governance.

In Hewson M and Sinclair TJ eds Approaches to Global Governance Theory Suny Press, Albany 23-53.

Smith A, Voß JP and Grin J 2010 Innovation studies and sustainability transitions: The allure of the multi-level perspective and its challenges Research policy 39 435-448.

Swyngedouw E 2009 The Antinomies of the Postpolitical City: In Search of a Democratic Politics of Environmental Production International Journal of Urban and Regional Research 33 601-620

Walker G 2015 Beyond individual responsibility: sustainable practices, capabilities and the case for a rights-based politics of social change. In Strengers, $\mathrm{Y}$ and Maller, $\mathrm{C}$ eds Social Practices, Intervention and Sustainability: Beyond Behaviour Change Routledge,London.

Walker G, Karvonen A and Guy S 2015 Zero carbon homes and zero carbon living: sociomaterial interdependencies in carbon governance Transactions of the Institute of British Geographers doi: 10.1111/tran.12090 
Zero Carbon Hub 2015 What we do http://www.zerocarbonhub.org/what-we-do. Accessed $21 / 7 / 2015$. 